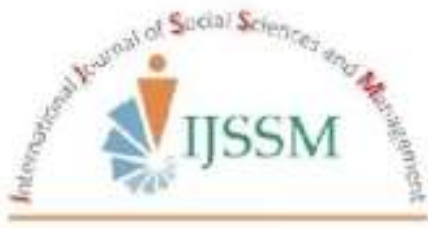

International Journal of Social Sciences and Management

Research Article

\title{
EFFECTIVENESS OF SOCIAL SAFETY NET PROGRAMS FOR POOR PEOPLE IN THE GOVERNMENT LEVEL OF BANGLADESH
}

\author{
Md. Ashraful Alam ${ }^{1}$ and Sheikh Abir Hossain ${ }^{2 *}$ \\ ${ }^{1}$ Institute of Social Welfare and Research, University of Dhaka, Bangladesh \\ $2^{*}$ Institute of Educational Development, BRAC University, Bangladesh \\ *Corresponding author email: sk.abir@hotmail.com
}

\begin{abstract}
Social Safety Nets (SSNs) and the wider topic of Social Protection have assumed a centrality within the development literature in recent years. Publicly-sponsored protection of the poor and vulnerable has emerged from the shadows to become a mainstream concern for policymakers. The contribution of SSNs is now viewed not merely in terms of their impact on challenged families, but their systemic benefits - in enabling higher levels of employment and entrepreneurship, sustaining household consumption and human capital, securing pro-poor growth and promoting social inclusion and national cohesion. A body of experience, ranging across continents, has now been established to inform the building of functional social protection systems. Yet in spite of this new consensus much controversy remains. A crucial first step in the development of a well-fitted national approach is the balancing of experience elsewhere with the national context. The ambit of SSNs in Bangladesh is often wide and fragmented. These typically include welfare payments, work guarantee schemes and conditional cash transfers; and comprise both on and off-budget allocations and a plethora of programs supported by donors. Gaining an understanding of the nature of provision and its functionality is another important first step in crafting a pro-development social protection system. This research provides information about different social safety net programs in government level. An attempt has been made to explore the effectiveness and the existing problems of current social safety net programs. The study also discusses the status and accessibility of beneficiaries in selected areas as well as advantages, limitations and prospects for social security in the context of this country. Besides, it also assesses the opinions of nonbeneficiaries who know more or less about the programs. Finally the paper suggests that there is a need to establish workable and sustainable effects among recipients. It also recommends that systematic efforts should be made urgently for the proper organization and management of safety net programs.
\end{abstract}

Key words: Effectiveness; Social Safety Net Programs; Government Level; Poor People

\section{Introduction}

Bangladesh is a developing country in the world. Its population is $1497,72,364$ (BBS, 2011). Over the past 40 years since independence, Bangladesh has increased its real per capita income by more than 130 percent, cut poverty rate by sixty percent, and is well set to achieve most of the millennium development goals. The economy today is lot more flexible and resilient, as indicated by the ability to withstand the global financial crisis with minimum adverse effects. Bangladesh also is now much more capable of handling natural disasters with minimum loss of life. Bangladesh achieved this remarkable progress with development despite numerous internal and external constraints (SFYP, 2011-2015). Notwithstanding this past progress, the Government recognizes that Bangladesh is still a low income country with substantial poverty, inequality and deprivation. The poor group of the population is severely disadvantaged in terms of ownership of assets and has inadequate access to institutional finance as well as to basic services including quality education, healthcare, water and sanitation. These people, and among them especially women and children, are also disproportionately affected by natural disasters and the adverse effects of climate change. Despite expansion, publicly supported mitigating measures in the form of social protection programs are still inadequate (SFYP, 20112015). The country has a patchwork of safety net programs (e.g., cash and in kind transfers, micro-credit schemes, and conditional cash transfers) for widows, the disabled, blind, orphans, the aged, to name just a few - each with its own large administrative overheads. But do they meet the needs? Coverage of these safety nets is very low and reaches a very small part of the target needy population. At the same time, despite the low coverage, multiple programs often serve the same beneficiary, and benefits go to those who do not need them (World Bank, 2006). In these circumstances, 
Bangladesh Government is operating various allowances under Social Safety Net programs such as: old age allowance, widow and deserted women allowance, allowance for the disabled, VGD, VGF, etc. As a citizen welfare centric country, Bangladesh is raring these programs through Department of Social Services, Department of Women Affairs, offices of the project implementation officers and various government offices (Shaikh,2004).

\section{Objectives of the Study}

1. To know socio-economic and demographic condition of the respondents.

2. To analyze the current programs under social safety nets in Bangladesh especially in poverty alleviation, education, health, sanitation and others.

3. To point out the impacts of social safety nets to meet their needs.

4. To find out gaps between services and demands and to take opinions of respondents to overcome that gaps.

\section{Methodology of the Study}

The study was a survey based exploratory research. The nature of the study was comparative. Experimental design was used in this study. Sample Survey and Focus Group Discussion (FGD) were used to collect data. Considering time and locality two villages named Noapara and Adorshapara at Uttarkhan thana in Dhaka District in Bangladesh were selected as study area. All people of selected villages were considered study population ranging 10 -80 years old. Married or unmarried both were included in this study. Every beneficiary and non-beneficiary was considered unit of analysis for collecting data and using interview. At first, it was done to identify the households through observation and secondary data based techniques in the study area. Then it was included on the basis of their socio economic condition. Total sample size was selected 101 (51 beneficiaries and 50 non-beneficiaries) through purposive sampling technique. To collect data from primary source, in-depth interview and observation technique as well as Focus Group Discussion (FGD) were followed. A written interview schedule was used for data collection. To collect slandered data, the interview schedule was pretested and the interview schedule contained some open ended and close ended questions. Moreover, the collected data from the field was classified according to its different characteristics then quantitative and qualitative data was processed and furnished as per requirement.

\section{Findings of the Study and Discussion}

\section{Majority of the respondents belong to 40-50 years age}

Majority of the respondent both beneficiaries(26\%) and non-beneficiaries (18\%) belongs to $40-50$ years age group and the lowest (2\%) for beneficiaries belongs to $70-80$ years age group and (4\%) non-beneficiaries belongs to 60-70 age group. $22 \%$ of the beneficiaries and $36 \%$ non-beneficiaries belong to10-20 years age group. $4 \%$ beneficiaries and $8 \%$ non-beneficiaries belong to 20-30 years age group. $16 \%$ beneficiaries and $18 \%$ non-beneficiaries belong to $30-40$ years age group. $20 \%$ beneficiaries and $16 \%$ nonbeneficiaries belong to 50-60 years age group and 10\% belongs to 60-70 year age group. The same result was identified in the research conducted by Glasso and Ravallion (2000).

\section{Female respondents are considerably greater than that of male}

10 are male that constitutes $20 \%$ and the rest 40 are female that constitutes $80 \%$ of the total beneficiaries. On the other hand, in non-beneficiary group $48 \%$ of total respondents are male and $52 \%$ respondents are female. The numbers of female respondents are considerably greater than that of male respondents both for beneficiaries and nonbeneficiaries. The similar result was found in research conducted by Iffath (2009)

\section{Majority of the respondents are married}

Majority of the respondents (beneficiaries 36\% and nonbeneficiaries $50 \%$ ) are married, $14 \%$ beneficiaries and $38 \%$ non-beneficiaries are unmarried, $30 \%$ beneficiaries and $8 \%$ non-beneficiaries are widow and $10 \%$ beneficiaries and $4 \%$ non-beneficiaries are divorced. This found results are similar to that of Rahman (2006)

\section{Majority of the respondents are Muslims}

Maximum respondents are Muslim (beneficiaries $86 \%$ and non-beneficiaries 98\%). $14 \%$ beneficiaries and $2 \%$ nonbeneficiaries are Hindu There is no Christian and Buddhist respondents in this study. Population census 2011 shows that, Muslim people are above $90 \%$ in our country. People from other religion are minimum in number and the same results were found in the research conducted by Subbarao (2002)

\section{Majority of the respondents are illiterate}

$38 \%$ of beneficiaries and $8 \%$ non-beneficiaries are illiterate, $34 \%$ beneficiaries and $14 \%$ non-beneficiaries complete their primary level. $26 \%$ both beneficiary and nonbeneficiary complete SSC level. $2 \%$ beneficiary and $34 \%$ non-beneficiary complete HSC level. $10 \%$ and $8 \%$ nonbeneficiaries complete Hon's and Master's level education. The similar results were found in the research conducted by Khandhker and Pitt (1998).

\section{Majority of the respondents are housewife}

Majority of the beneficiaries (54\%) are housewife and nonbeneficiaries are students, $22 \%$ beneficiaries are students, $16 \%$ are businessman and $8 \%$ are employee. $20 \%$ nonbeneficiaries are housewife, $20 \%$ are businessman, $24 \%$ are 
employee. The same results were found in the research that was conducted by Khanum (2000).

\section{Majority of the respondents have no income}

$76 \%$ beneficiaries are mentioned on 000-5000/- income category majority of them have no income. They mentioned the service money is their only income. $22 \%$ earns between 5000-10000/-. Only 2\% earns above 10000/-. 76\% 0f beneficiaries mention that they have expenditure between 000-5000/- tk although they have no income source. $22 \%$ mentioned their expenditure between 5000-10000/-. 2\% mention that their expenditure is above $10000 /-.48 \%$ nonbeneficiaries are mentioned on 000-5000/- income category majority of them have no income.. $28 \%$ earns between 5000-10000/-. $14 \%$ earns above 10,000/- tk. 50\% of beneficiaries mention that they have expenditure between 000- 5000/- tk. $28 \%$ mentioned their expenditure between 5000-10000/-. 22\% mention that their expenditure is above 10000 taka. Thing is that the similar results were found in the research conducted by Tabor (2002).

\section{Majority of the respondents have no monthly savings}

Majority of the beneficiaries (98\%) mentions that they have no monthly savings. Only $2 \%$ mention about savings. Majority of the non-beneficiaries (76\%) mentioned that they have no monthly savings. Only $24 \%$ mention about savings and the same results were found in the research that was conducted by Begum and Majumder (2001).

\section{Majority of the respondents belong to nuclear family}

$76 \%$ of total beneficiaries belongs to nuclear family and $24 \%$ belongs to extended family. $16 \%$ of total beneficiaries has building, 20\% live in semi-building, 36\% has tin-shed house and $28 \%$ has kaccha house. $50 \%$ use kaccha toilet, $22 \%$ use pucca toilet, $26 \%$ use semi pucca and $2 \%$ use open place as toilet. $24 \%$ has own land and $76 \%$ has no land of their own. $56 \%$ use their own tube well as water source and $44 \%$ use tube well of others. On the other hand, $72 \%$ of the total non-beneficiaries belongs to nuclear family and $28 \%$ belongs to extended family. $16 \%$ non-beneficiaries have houses made of soil, $44 \%$ have building, $26 \%$ have semi building and $14 \%$ have tin shed residence., $12 \%$ nonbeneficiaries use toilet made of soil, $68 \%$ use packa $18 \%$ have semi packa and $2 \%$ non-beneficiaries uses open place as toilet. The table also mentions that $36 \%$ non-beneficiaries has their own land and $64 \%$ non-beneficiaries has no own land. In this table, we can see that the non-beneficiaries uses water for daily workers form own tube well and other houses tube well. Here, $80 \%$ use own tube well and only $20 \%$ use other houses tube well for drinking and other workers. The same results were found in the research conducted by Alderman (2002).

\section{Majority of the respondents take three-time meal}

Majority of the beneficiaries (78\%) takes food three times. $20 \%$ takes food 2 times and only $2 \%$ takes food 4 times. Most of the non-beneficiaries (58\%) takes food three times.
$8 \%$ takes food 2 times and $34 \%$ takes food 4 times. Most of the respondent takes rice, fish and vegetable as their main food. The same results were found in the research conducted by Ahmad (2007).

\section{Majority of the respondents take rice as main food}

27 of total beneficiaries eat rice in the morning, and 23 beneficiaries eat rice at night. All of the beneficiaries take rice as major food at noon. 17 beneficiaries take fish with rice in the morning, 26 beneficiaries take it at lunch and only 3 beneficiaries teat fish at dinner. 2 beneficiaries mention that they eat meat at breakfast, 25 eat meat at lunch and 2 beneficiaries eat meat at dinner. 8 beneficiaries mention that they take daal at breakfast and 33 beneficiaries eat daal at lunch. 37 beneficiaries eat vegetable at breakfast, 32 beneficiaries eat at lunch and 28 beneficiaries eat at dinner. 22 beneficiaries eat egg at night, 19 beneficiaries eat at lunch and only 3 beneficiaries eat it at dinner.42 beneficiaries eat bread at breakfast and the same number of beneficiaries eat it at dinner. 38 beneficiaries take tea after breakfast and 45 beneficiaries take tea at afternoon. Only 8 beneficiaries mentioned that the ear fruit at afternoon. 16 of total non-beneficiaries eat rice in the morning, and $31 \mathrm{n} 0 \mathrm{n}$ beneficiaries eat rice at night. All of the n0n-beneficiaries take rice as major food at noon. 14 non-beneficiaries take fish with rice in the morning, 38 non-beneficiaries take it at lunch and only 29 non-beneficiaries eat fish at dinner. 4 non-beneficiaries mention that they eat meat at breakfast, 33 eat meat at lunch and 16 respondents eat meat at dinner. 19 respondents mention that they take daal at breakfast and 23 non-beneficiaries eat daal at lunch. 44 respondents eat vegetable at breakfast, 38 respondents eat at lunch and 36 respondents eat at dinner. 18 respondents eat egg at night, 42 respondents eat at lunch and only 27 respondents eat it at dinner.32 respondents eat bread at breakfast and 23 respondents eat it at dinner. 31 respondents take tea after breakfast and 45 respondents take tea at afternoon. Only 8 respondents mentioned that the ear fruit at afternoon. The similar results were found in the research conducted by Chowdhury and Alam (1997).

\section{Majority of the respondents suffered from fever}

$30 \%$ of the beneficiaries suffers from fever and cough in last 6 months. $26.67 \%$ suffers from stomach problem, $3.30 \%$ suffers from skin disease and $3.30 \%$ suffers from TB, $6.66 \%$ typhoid, $10 \%$ from tooth problem, $11.67 \%$ respiratory problem and $8.33 \%$ from heart disease. $86 \%$ of the beneficiaries takes treatment and $14 \%$ takes no treatment. Majority of the beneficiaries takes treatment from allopathic doctors, $8 \%$ from homio doctor, $12 \%$ from kobiraj and $14 \%$ from quack. On the other hand, $54 \%$ of the nonbeneficiaries suffers from fever and cough in last 6 months. $127 \%$ suffers from stomach problem, $6 \%$ suffers from skin disease, $6 \%$ from tooth problem, $8 \%$ respiratory problem and $14 \%$ from heart disease. $80 \%$ of the non-beneficiaries takes treatment and $20 \%$ takes no treatment. Majority of the 
non-beneficiaries $(62.5 \%)$ takes treatment from allopathic doctors, $12.5 \%$ from homio doctor, $7.5 \%$ from kobiraj and $17.5 \%$ from quack. The same similar results were found in the research conducted by Rahman (2006).

\section{Majority of the respondents take monetary fund}

$32 \%$ of the respondent get old age and widow allowance, $30 \%$ GET VGD, $16 \%$ get VGF and $22 \%$ get stipend. $54 \%$ get service in monetary fund and they take service directly from bank. $46 \%$ gets service as goods. These $46 \%$ get service from member of Union Parishad. The same results were found in the research conducted by UNDP (2011).

\section{Majority of the respondents cannot fulfill their educational need}

In education $12 \%$ respondents think that program can fulfill their educational need very little. $14 \%$ mention rough fulfillment of their need, $4 \%$ mention much fulfillment of their need, $4 \%$ mention very much fulfillment of need and $66 \%$ mention that it does not fulfill their need at all. In food security $16 \%$ mention that it fulfills food need little, $8 \%$ mention very little fulfillment of need, $56 \%$ mention rough fulfillment of needs and $20 \%$ mention their food needs is not fulfilled by these services at all. $14 \%$ mention little fulfillment of needs, $30 \%$ mention very little fulfillment of needs, $13 \%$ mention rough fulfillment of needs and $44 \%$ mention that these services do not fulfill their needs during disaster and hazard at all. $12 \%$ respondents mention little fulfillment of needs, $24 \%$ mention very little fulfillment of needs, $14 \%$ mention rough fulfillment of needs $2 \%$ mention much fulfillment of needs and $48 \%$ mention that their treatment need is fulfilled not at all by these services. The same results were found in the research conducted by Baulch (2011).

\section{Majority thinks that social safety net programs have no impact on education \\ $76 \%$ respondent think that social safety net program have no impact on education while $24 \%$ think that it has impact on education like increase of literacy $(33.3 \%)$, increase of going to school (25\%), awareness of education $(25 \%)$, facility for higher education.}

\section{Majority thinks rough surety of sanitary environment}

$48 \%$ respondent mention rough surety of sanitary environment, $16 \%$ mention about little surety, $24 \%$ mention about very little surety and $12 \%$ mention no surety of sanitary environment by the obtained service. All of the respondent think that it has no impact on health. The similar results were found in the research conducted by Abrahart $e t$ al. (2004).

\section{Majority of the respondents know the safety net programs}

In this study, $88 \%$ of total respondent know about the safety net programs and $12 \%$ of respondent have no idea about safety net programs. $34.5 \%$ out of all who know about safety net program know from their neighbor. $27.3 \%$ know from their relative, $15.9 \%$ know from field worker, $18.2 \%$ know from service receiver and $4.5 \%$ know from the member of union parishad. Majority of the respondents (34.1\%) know about old age and widow allowances and stipend. $15.9 \%$ know about VGD and $6.8 \%$ know about VGF program. The similar results were found in the research conducted by Abrahart et al. (2004).

\section{Majority thinks that social safety net programs have no impact on socio-economic development}

$8 \%$ respondent think that social safety net program have no impact on socio-economic development, while majority of the respondent think that it has a impact on socio-economic development. The similar results were found in the research conducted by Chowdhury and Alam (1997).

\section{Majority said that social safety net program could develop their present condition}

$84 \%$ non-beneficiaries think that social safety net program could develop their present condition if they get the service and $16 \%$ respondents think that it could not improve their present condition even if they get the services. The same results were found in the research conducted by Alderman (2002)

\section{Majority preferred to get old age and widow allowance}

$28 \%$ of the total non-beneficiaries prefer to get old age and widow allowance, $24 \%$ prefer to get VGD, $16 \%$ prefer to get VGF and $32 \%$ prefer to get stipend as social safety net program. The same results were found in the research conducted by Shaikh (2004).

\section{Majority said that socio economic condition of beneficiaries is better}

$18 \%$ beneficiaries think that socio economic condition of beneficiaries is better than that of non-beneficiaries and $82 \%$ think that socio economic condition of beneficiaries is not better than that of non-beneficiaries. On the other hand, $42 \%$ non-beneficiaries think that socio economic condition of beneficiaries is better than theirs and $58 \%$ think that socio economic condition of beneficiaries is not better than theirs. The same results were found in the research conducted by Fernando (2004).

\section{Services are not sufficient}

$34 \%$ beneficiaries think that services are sufficient and $66 \%$ think that services are not sufficient. On the other hand $76 \%$ non-beneficiaries think that services are sufficient and $24 \%$ think that services are not sufficient and the same results were found in the research conducted by Chowdhury and Alam (1997).

\section{Ethical Consideration of the Study}

As researchers it was important for us to be sensitive and respectful to the participants' culture, life styles, language, context and environment. We also tried to avoid dominating tendency and behaved well toward them. We assured the 
participants that the collected data would not be disclosed and we would maintain confidentiality and these data would only be used for research purpose. We took their interview in their selected time and places. We sought permission from the participants by a consent letter for collecting information, and for using tape recorder during the interview. We explained our goals to the participants and how this information would be used. Moreover, we showed patience and listened attentively. We also informed the participants that they are free to withdraw from the study at any time without penalty.

\section{Recommendations}

During conducting this research, we noticed different problems and limitations in social safety net programs and their delivery system those are as follows:

1. The government should allocate sufficient portion of national budget for social safety net programs and should ensure properly release of that money.

2. Social safety net programs should be monitored from the high level of government to ensure transparency and accountability.

3. The most important thing is that amount and quantity of service must be increased. The present amount is very poor and insufficient and not enough to meet their necessity. Especially old age allowance, VGD, and VGF should be increased on priority basis.

4. Most of the receivers face different kinds of harassment in selection process and in getting service. So, steps should take to remove all kinds of harassment.

5. Many service holders sell their obtained goods to meet other monetary needs. Consequently they have food crisis. The concerned authority should be conscious and create awareness among them for using in the best way.

6. Relatives, neighbors, and surrounding people should help the service holders so that they can properly use of their obtained goods and money and develop their socio-economic conditions

7. Many gave objections that services are given at very late. So, they cannot use in proper way and for expected area. That is why, SSNPs should be provided at proper time on the regular basis.

8. Seminars, symposium, workshop, effective discussion etc. should be arranged for improving the knowledge, attitude, psychosocial conditions and SSNPs programs.

9. Social media can play a vital role to make the beneficiaries conscious and responsibility about objectives of SSNPs programs, effectiveness, ways of the best use etc.
10. Many international organizations and foreign countries contribute in SSNPs. Although the government implements the programs, the donors should supervise and monitor along with government to ensure transparency and accountably.

11. In research findings we have seen that the amount of service-either money or goods-is very poor not enough to fulfill their any single needs. So, amount and quantity of service should be increased.

12. Social negligence should be avoided through creating awareness among social people. They are human and social being like us. They have rights to lead a standard life. So, we should come forward to help them in different ways.

13. Some incentives should be provided beside social safety net programs to increase effectiveness of the given programs.

14. Social workers can play a vital role in increasing effectiveness of these programs by creating awareness, policy making, social action, social research etc.

15. During conducting the study we have deeply noticed pervasive lack of coordination among different implementing organizations, departments and ministries. So, an effective and regular coordination and interaction should be ensured.

16. In operating these programs, national and international NGOs should be included. Because they have close contact and relation with mass people.

17. Overall, all people who are engaged in SSNPs should be attentive, sincere, dedicated, and humanitarian.

18. Acknowledgement

First of all, we would like to express our deepest admiration and respect to the authority of our Institute to give us approval to conduct this research. Besides, we would like to give thanks to the people and organization that provided us necessary documents to complete our works. Finally, we do deliver our love to those participants who gave us their valuable time at the time of data collection.

\section{References}

Abrahart AS, Ahmed A, and Sundararaman V (2004) Safety Net Programs in Bangladesh. Prepared as Background Paper for Social Safety Nets in Bangladesh: An Assessment. World Bank.

Ahmad QK (2007) Socio-Economic and Indebtedness-Related Impact of Micro-Credit in Bangladesh. The University Press Limited (UPL), Dhaka 
Akhter AU et al. (2007) Relative Efficacy of Food and Cash Transfers in Improving Food Security and Livelihoods of the Ultra-poor in Bangladesh, International Food Policy Research Institute (IFPRI).

Alderman (2002) Subsidies as Social Safety Nets: Effectiveness and Challenges, Social Protection Discussion Paper Series, No. 0224, World Bank.

Bangladesh Bureau of Statistics (BBS) (2012) Planning Division, Ministry of Bangladesh, Dhaka.

Baulch B (2011) The medium-term impact of the primary education stipend in rural Bangladesh. Journal of Development Effectiveness 3(2): 243--262.

Begum S and Majumder PP (2001) The Allowance Scheme for Widowed and Husband Deserted Women in Bangladesh: Some Field Level Information. The Bangladesh Institute of Development Studies, Dhaka, (mimeographed).

Chowdhury M and Alam A (1997) BRAC's poverty Reduction programme: what it is and what it achieved? Who Needs Credit: Poverty and Credit in Bangladesh, UPL / Zed Books, Dhaka / London.

Fernando PF (2004) A Statistical Handbook on the Social Safety Nets; Greenwood Press, 88 Post Road West, West Post CT, USA.

Galasso E and Ravallion M (2000) Distributional Outcomes of a Decentralized Welfare Program. Policy Research Working Paper 2316, World Bank.

Iffath AS (2009) Building a Targeting System for Bangladesh based on Proxy Means Testing, World Bank Social Protection Discussion Paper.
Khandhker S and Pitt M (1998) The Impact of Group-Based Credit Programs on Poor Households in Bangladesh: Does the Gender of Participants Matter? Journal of Political Economy.

Khanum SM (2000) Knocking at the Doors: The Impact of RMP on the Womenfolk in the Project Adjacent Areas. Journal of the Institute of Bangladesh Studies, Vol. XXIII.

Rahman HZ (2006) Safety Nets and Safety Ladders: Exploring a Comprehensive Approach to Social Protection in Bangladesh, PPRC/GED, Planning Commission, Government of Bangladesh

Shaikh A (2004) Delivery Mechanism for Cash Transfer Programs to the Poor. Social Protection Discussion. Paper Series 0520, World Bank.

Sixth Five Year Plan (2011-2015) Accelerating Growth and Reducing Poverty. General Economics Division. Planning Commission. Ministry of Planning, Government of the People's Republic of Bangladesh.

Subbarao K (2002) Systemic Shocks and Social Protection: Role and Effectiveness of Public Works Programs. Social Protection Discussion Paper Series; No. SP 0302, World Bank.

Tabor S (2002) Assisting the Poor with Cash: Design and Implementation of Social Transfer Programs. Social Protection Discussion Paper Series 0223, World Bank.

United Nations Development Programme (UNDP) (2011) Social Safety Nets in Bangladesh. Volume1: Review of Issues and Analytical Inventory. 